\title{
Pig slurry as a nutrient source in wheat/corn succession
}

\author{
Claudir José Basso ${ }^{1}$, Marlo Adriano Bison Pinto ${ }^{1 *}$, Antônio Luis Santi, \\ Rodrigo Ferreira da Silva ${ }^{1}$, Diecson Ruy Orsolin da Silva ${ }^{1}$
}

10.1590/0034-737X201663030019

\begin{abstract}
Wheat and corn are important grains in the agricultural scenario of Brazil, and demand adequate supply of nutrients, particularly nitrogen, in crop succession. The use of pig slurry (PS) as a full and/or partial alternative to mineral fertilization in crop areas has been identified as an important alternative for the disposal of this waste. Therefore, the objective of this study was to evaluate the utilization of PS as fertilizer in wheat/corn succession under some plant parameters and grain yield. The experiment was conducted under field in randomized block design with four replications and five treatments, three with PS $\left(40,80,160 \mathrm{~m}^{3} \mathrm{ha}^{-1}\right)$ and two controls (no fertilization and mineral NPK fertilization), which were applied manually in the soil shortly after sowing the crops. The application of PS proved to be a significant source of nutrients in wheat/corn succession. In comparison to NPK fertilization, this increase was only of 5.4\% and $4.7 \%$ for wheat and corn, respectively. PS is an efficient alternative and it can be used as a source of these nutrients in wheat/corn succession, and the use of $80 \mathrm{~m}^{3} \mathrm{ha}^{-1}$ provides satisfactory results for all evaluated variables.
\end{abstract}

Keywords: organic fertilizer, nutrient accumulation, Zea mayz L., Triticuma estivum L.

\section{RESUMO}

\section{Dejeto líquido de suínos como fonte de nutrientes na sucessão trigo/milho}

O trigo e o milho são cereais importantes no cenário agropecuário do país, que demandam adequado suprimento de nutrientes, principalmente o nitrogênio, quando do cultivo em sucessão. A utilização de dejeto líquido de suínos (DLS) como alternativa total e/ou parcial a fertilização mineral em áreas de lavoura tem sido apontada com uma importante alternativa de descarte desse resíduo. Por isso, o objetivo do presente trabalho foi avaliar o efeito da utilização de DLS como fertilizante na sucessão trigo/milho sobre alguns parâmetros de planta e na produtividade de grãos. O experimento foi conduzido a campo no delineamento blocos ao acaso com quatros repetições e cinco tratamentos, sendo três com DLS $\left(40 ; 80 ; 160 \mathrm{~m}^{3} \mathrm{ha}^{-1}\right)$ e duas testemunhas (sem fertilização e fertilização NPK mineral), os quais foram aplicados manualmente sobre o solo logo após a semeadura das culturas. A aplicação de DLS mostrou-se uma importante fonte de nutrientes a sucessão trigo/milho. O DLS é uma alternativa eficiente e pode ser utilizado como fonte desses nutrientes na sucessão trigo/milho, sendo que o uso de $80 \mathrm{~m}^{3} \mathrm{ha}^{-1}$ proporciona resultados satisfatórios para todas as variáveis avaliadas.

Palavras-chave: adubo orgânico, acúmulo de nutrientes, Zea mayz L., Triticuma estivum L.

\footnotetext{
Submitted on June $18^{\text {th }}, 2015$ and accepted on March $29^{\text {th }}, 2016$.

${ }^{1}$ Universidade Federal de Santa Maria, Departamento de Ciências Agronômicas e Ambientais, Frederico Westphalen, Rio Grande do Sul, Brasil. claudirbasso@gmail.com; marlo.bison@gmail.com; santi_pratica@yahoo.com.br; rodrigosilva@smail.ufsm.com

*Autor para correspondência: marlo.bison@gmail.com
}

Rev. Ceres, Viçosa, v. 63, n.3, p. 412-418, mai/jun, 2016 


\section{INTRODUCTION}

Wheat and corn are staple foods for mankind and corn is also important raw material in the formulation of feed for pig and poultry farming. In recent decades, there has been a significant demand for these grains in the domestic market, driving technologies towards increasing yield and quality of the grains. Brazil is not self-sufficient in wheat production and this is caused by a lot of insecurity of the framers due to either lack of a guaranteed minimum price, or by adverse weather in the South region, its leading producer. Crop failure or low prices may not be enough to pay even the production costs, in which $40 \%$ is consisted of modern inputs (Brum \& Heck, 2005). On the other hand, corn is important for crop rotation. The increase in grain production, is due more to vertical productivity associated to new technologies than the actual increase in the cultivated area. Fertilizers have the most impact on the final cost of corn production (Araujo et al., 2004), which has high demand for nitrogen fertilization (Gomes et al., 2007; Duete et al., 2008), because nitrogen (N) is a vital plant nutrient, responsible for the formation of various organic compounds and activation of enzymes (Malavolta, 2006). Despite the requirement of nitrogen not being as high in wheat compared to corn (Commission of Chemistry and Soil Fertility - CQFS 2004), an adequate supply of N has been considered vital for desirable industrial quality of grains (Cazetta et al., 2008; Pinnow et al., 2013).

The production chain of swine is one of the major income-generating activities in small farms in southern Brazil, and more recently, it has been expanding to the central west region of the country, which is a significant region in corn production, the main component in animal diet. However, due to the intensification of swine farming in these regions, there is a high supply of pig slurry (PS) which, according to Konzen (1983), consists of the animal hairs, feces, urine, leftover feed, water from troughs and cleaning of the stalls, and other residues resulting from the adopted management practices.

PS has fertilizing and pollutant potential, and caution in its use with agricultural crops has already been documented, especially as a source of $\mathrm{N}$, phosphorus (P) and potassium (K) (CQFS, 2004; Ceretta et al., 2005; Konzen, 2006; Seidel et al., 2010; Correa et al., 2011; Costa et al., 2011; Cassol et al., 2012). Besides being a way of disposing this waste, its use in agricultural crops is a way of alleviating pollutant potential and providing the cycling of these nutrients within their own production units.

In this sense, some studies have aimed to evaluate the effect of PS on the production of cover crops in winter (Ceretta et al., 2005; Aita et al., 2006), on the decomposition of straw on the surface (Aita et al., 2006; Giacomini et al., 2008), on soil nutrients and chemical properties (Lourenzi et al., 2011; Lourenzi et al., 2013) and on the dynamics of transformation of nitrogen in the soil (Aita et al., 2006; Aita \& Giacomini, 2008). However, little is known of its nutritional value in two important gramineae, seen as major exporters of nutrients and grown in succession. Therefore, the aim of this study was to evaluate the effect of PS as fertilizer on plant growth and yield in wheat/corn succession.

\section{MATERIAL AND METHODS}

The experiment was conducted on field in the period of June 2012 to March 2013. The soil of the experimental area is classified as Rhodic Eutrudox, (Embrapa, 2006) and the climate as subtropical climate with hot summers ( $\mathrm{CFa}$ ) according to Köppen classification system (Moreno, 1961). Rainfall during the period is presented in Figure 1.

The area where the experiment was conducted had been cultivated under no-tillage system over the last 10 years, the last year remaining under fallow. In March 2013, three months before the sowing of wheat and the installation of the experiment, sampling was conducted in soil layer $0-10 \mathrm{~cm}$ and it presented the following characteristics: $\mathrm{pH}(1: 1$ in water $)=4.8 ; \mathrm{SMP}$ index $=5.5$; clay $=650 \mathrm{~g} \mathrm{~kg}^{-1}$, organic matter $=29 \mathrm{~g} \mathrm{~kg}^{-1}$; potassium $=$ $252 \mathrm{mg} \mathrm{dm}^{-3}$, calcium $=3.4 \mathrm{cmol}_{\mathrm{c}} \mathrm{dm}^{-3} ;$ magnesium $=1.7$ $\mathrm{cmol}_{\mathrm{c}} \mathrm{dm}^{-3}$, aluminum $=1.0 \mathrm{cmol}_{\mathrm{c}} \mathrm{dm}^{-3}$, phosphate $=13.00$ $\mathrm{mg} \mathrm{dm}{ }^{-3}$. Seeking to increase $\mathrm{pH}$ to 6.0 , liming was also done in March as recommended (CQFS, 2004), followed by subsoiling and plowing operations.

The experimental design was in randomized blocks with six treatments and four replications structured in plots of 9 $\mathrm{m}^{2}$. The treatments were three doses of PS $\left(40,80,160 \mathrm{~m}^{3}\right.$ $\mathrm{ha}^{-1}$ ), mineral NPK, and no fertilization, as the bottom control. Mineral NPK fertilization was quantified as recommended for each crop (CQFS, 2004) with an expected yield of $3.0 \mathrm{Mg} \mathrm{ha}^{-1}$ for wheat and $12 \mathrm{Mg} \mathrm{ha}^{-1}$ for corn. Urea $\left(175 \mathrm{~kg} \mathrm{ha}^{-1}\right)$, triple superphosphate $\left(150 \mathrm{~kg} \mathrm{ha}^{-1}\right)$ and potassium chloride (100 kg ha-1) were used as the source of NPK, respectively. PS was obtained from a swine production unit in the region, whose characterization and respective amounts of $\mathrm{N}, \mathrm{P}\left(\mathrm{P}_{2} \mathrm{O}_{5}\right)$ and $\mathrm{K}\left(\mathrm{K}_{2} \mathrm{O}\right)$ added to each treatment and crop is shown in Table 1. The treatments were applied by casting after sowing of crops, while $\mathrm{N}$ coverage was done at wheat tillering (30 days after emergence) and V4 for corn.

The sowing of wheat (cultivar Quartzo, classified as bread wheat, of medium cycle and plant height) was manual, in rows spaced at 0.17 meters, density of 300 viable seeds per square meter. The sowing of corn (DKB $250 \mathrm{VT}$ Pro) was spaced at $0.45 \mathrm{~m}$, performed manually, with a density of 6.30 seeds per linear meter, thus ensuring population of 70,000 plants ha ${ }^{-1}$ after thinning. 
The dry matter (DM) of the shoots at flowering was evaluated, which for wheat was measured when $50 \%$ of the plot had spikes in bloom, and for corn when $50 \%$ of the spikes had exposed stigmas. For wheat, this assessment was made by cutting the plants close to the ground in an area of $0.25 \mathrm{~m}^{2}$ in each plot. For corn, sampling was done on five random plants in the plot. Samples were taken to a circulating air oven at $65{ }^{\circ} \mathrm{C}$ until constant weight. After being dried, the samples were weighed and crushed in electric forage, and homogenized; a sub sample was then removed and referred to the laboratory for tissue analysis to determine the content of N, P and, K. In the laboratory, samples were ground in a Willey grinder, proceeding to the wet digestion method described by Tedesco et al. (1995).

Close to harvest, ten random plants of the plot were evaluated as regards plant height $(\mathrm{PH})$, having the ground level and the insertion of the flag leaf as reference for both crops. For wheat, the number of grains per spike (G/S), and for corn, stem diameter (SD) were measured with a digital caliper at the height between the first and second node of the stem.

For wheat, the plants were harvested in an area of 2.72 $\mathrm{m}^{2}$ from the center of each plot, and for corn, cobs were collected from ten random plants, disregarding the borders of the plot. The determination of yield was calculated after threshing, cleaning and correction of humidity (13\%), considering the harvested area of wheat and the number of plants harvested for corn. The weight of a thousand grains (TGW) was determined for both crops using four replications of 100 units of each plot and for wheat, the hectoliter weight (HW) was measured through a specific device in an unloading grain cooperative in the region.

The analysis of variance was carried out and when significant, the Dunnett test was applied to compare each treatment of PS with each control at $5 \%$ error probability ( $p$ $>0.05$ ), using the software GENES (Cruz et al., 2006).

\section{RESULTS AND DISCUSSION}

As regards dry matter (DM) yield in the shoots of wheat, Table 2 shows an increase of 26, 52 and 33\%, respectively, for doses of $40,80 \mathrm{e} 160 \mathrm{~m}^{3} \mathrm{ha}^{-1}$, compared to the production without fertilizer application, but not significantly differing from that obtained with mineral fertilizer. The $52 \%$ oppose the $34 \%$ found by Assmann et al. (2007) in DM yield in oats+rye grass intercropping, and the $104 \%$ found by Aita et al. (2006) in black oat in monoculture when using $80 \mathrm{~m}^{3} \mathrm{ha}^{-1}$.

This DM response may be associated with the amount of nutrients applied via PS, because even at the lowest dose of PS $\left(40 \mathrm{~m}^{3} \mathrm{ha}^{-1}\right)$, sufficient nutrients were added and nutritional demand of $\mathrm{N}, \mathrm{P}$ and $\mathrm{K}$ in wheat was met, similarly to mineral fertilization (Table 1). Even without significant difference, the highest DM yield in the shoots of wheat was achieved with the dose of $80 \mathrm{~m}^{3} \mathrm{ha}^{-1}$ which would approximate doses of 65 and $86 \mathrm{~m}^{3} \mathrm{ha}^{-1}$, respectively found by Aita et al. (2006) and Ceretta et al. (2005), and maximum technical efficiency in the black oat yield.

In corn, there was no difference in DM yield among doses of pig slurry and mineral fertilizer control. However, compared to control without fertilizer, there was an increase in DM yield of 35.03, 44.25 and $44.35 \%$ for doses of 40,80 e $160 \mathrm{~m}^{3} \mathrm{ha}^{-1}$ of PS, respectively. It was observed that, by doubling the amount of PS from 80 to $160 \mathrm{~m}^{3} \mathrm{ha}^{-1}$, the increase in DM yield was insignificant, which, according to Ceretta et al. (2005), nutritional inefficiency occurs by PS with the increase of the dose, as found by doubling the dose of 40 to $80 \mathrm{~m}^{3} \mathrm{ha}^{-1}$. Using $63.3 \mathrm{~m}^{3} \mathrm{ha}^{-1}$ of PS as the source of $140 \mathrm{~kg} \mathrm{~N} \mathrm{ha}^{-1}$ in growing wheat on oat straw, Giacomini \& Aita (2008) did not find any difference in DM yield compared with mineral fertilization. However, in comparing these studies, it is interesting to note that soil, straw, hybrid and PS between both are different. In addition, the treatment of only $40 \mathrm{~m}^{3} \mathrm{ha}^{-1}$ of PS presented a similar

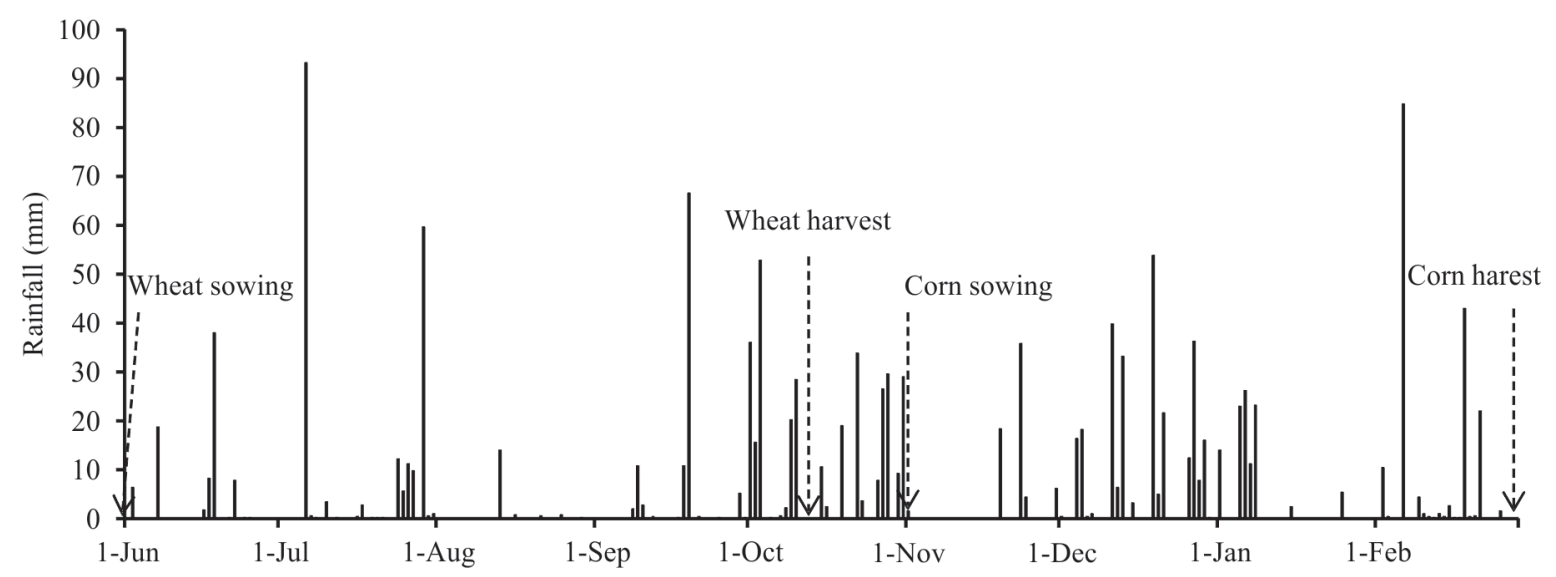

Figure 1: Distribution of rainfall during the study period. Data collected from the meteorological station INMET (National Institute of Meteorology), located 1000 meters from the experiment.

Rev. Ceres, Viçosa, v. 63, n.3, p. 412-418, mai/jun, 2016 
response to the mineral control, as opposed to the necessary $63.3 \mathrm{~m}^{3} \mathrm{ha}^{-1}$ of the authors. This can also be associated with the amount of readily available $\mathrm{N}$ (ammonium) supplied via the PS, which was $57.9 \mathrm{~kg} \mathrm{ha}^{-1}$ in the work of Giacomini \& Aita (2008) and $74.4 \mathrm{~kg} \mathrm{ha}^{-1}$ in the present work.

The number of G/S in wheat crop did not differ with the application of PS compared to any of the controls. If the high input of nitrogen by PS is considered, Teixeira Filho et al. (2010) found no response in number of $\mathrm{G} / \mathrm{S}$ when nitrogen fertilization in irrigated wheat crop was studied. However, Cazetta et al. (2008) and Espindula et al. (2010) found positive linear response to the number of $\mathrm{G} / \mathrm{S}$ with increasing doses of $\mathrm{N}$ in wheat up to $120 \mathrm{~kg} \mathrm{ha}^{-1}$.

Wheat PH had an increase of $5.5 \mathrm{~cm}$ at the dose of 160 $\mathrm{m}^{3} \mathrm{ha}^{-1}$ of PS compared to mineral fertilizer control (Table 2). This response, by increasing doses of $\mathrm{N}$ via PS, corroborates the work of Espindula et al. (2010) who found linear and positive response of wheat $\mathrm{PH}$ with increased supply of N. Greater plant height is possibly associated not only to the high input of readily available $\mathrm{N}(411.2 \mathrm{~kg}$ $\left.\mathrm{ha}^{-1}\right)$, in relation to the demand of the crop $\left(60 \mathrm{~kg} \mathrm{ha}^{-1}\right)$, but may also be more closely related to the anticipation of $\mathrm{N}$ supply. It depends on the PS having been all applied at sowing in relation to mineral NPK, corroborating the results of Teixeira Filho et al. (2008) in which all the nitrogen was applied in early sowing of wheat, as not all genotypes respond to different doses of $\mathrm{N}$.

Corn PH was not lower in the PS treatments compared to mineral NPK. However, compared to the control without fertilizer, it was equal to the treatment with $40 \mathrm{~m}^{3} \mathrm{ha}^{-1}$ of PS and superior to the others. The variable SD was superior when applying $160 \mathrm{~m}^{3} \mathrm{ha}^{-1}$ of PS, supporting Mata et al. (2010) who found a gain in the use of cattle manure,

Table 1: Characteristics of pig slurry in $\mathrm{N}$ (total $\mathrm{N}$ and $\left.\mathrm{N}-\mathrm{NH}_{4}{ }^{+}\right), \mathrm{P}\left(\mathrm{P}_{2} \mathrm{O}_{5}\right), \mathrm{K}\left(\mathrm{K}_{2} \mathrm{O}\right), \mathrm{DM}$ (Dry matter), pH, density and respective amounts added to the system by each treatment in the fertilization of wheat and corn

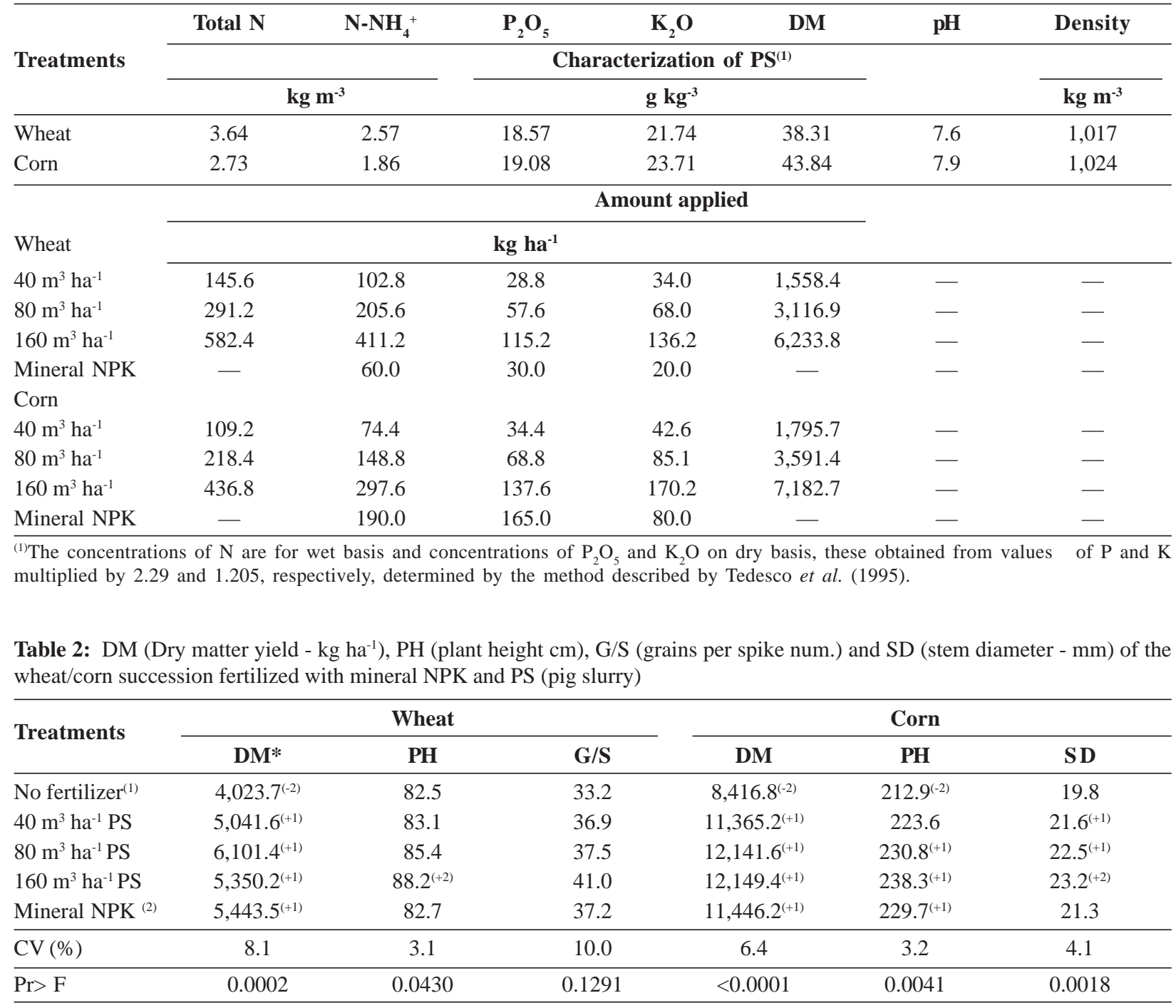

${ }^{(1)}$ No fertilizer control, ${ }^{(2)}$ Mineral NPK control; *Means followed by: ${ }^{(+2)}$ significant and higher than the mineral NPK control, ${ }^{(+1)}$ significant and higher than no fertilizer control; ${ }^{(-2)}$ significant and lower than mineral NPK by Dunnett test at $5 \%$ probability. 
compared to mineral fertilization. The highest SD demonstrates an adequate nutrition of crop because Cruz et al. (2008) and Soratto et al. (2010) found positive response to this variable with increasing $\mathrm{N}$ supply, including a favorable correlation with grain yield, justifying that well-nourished corn plants use the stem as a reserve structure for the supply of grains. Although, such nutritional benefit was observed, attention is brought to the importance of a balanced supply of nutrients most required by the crop, and not only a single nutrient, as shown in Table 1, where the treatment showed excess of $\mathrm{N}$ and a low addition of $\mathrm{P}$ compared to the culture demand.

With regard to the accumulation of $\mathrm{N}, \mathrm{P}$ and $\mathrm{K}$ by the $\mathrm{DM}$, it can be inferred in general concerning the cultures and the three elements, that the dose of $80 \mathrm{~m}^{3} \mathrm{ha}^{-1}$ of PS favors accumulation of these nutrients in relation to the two controls (Table 3), with higher accumulation than the control without fertilization and not lower than the mineral fertilization control.

These results show the fertilizing potential of PS with satisfactory accumulation of nutrients in DM, as evidenced by Aita et al. (2006). It was also observed that the accumulation of such nutrients increased as quantities of PS were doubling. However, the supply of $160 \mathrm{~m}^{3} \mathrm{ha}^{-1} \mathrm{did}$ not provide greater accumulation than the mineral fertilizer control, showing a loss of efficiency in the absorption of these elements, which could encumber yield with the transportation of waste, and enhance environmental hazards. Cerreta et al. (2005) found a positive response for the accumulation of $\mathrm{N}, \mathrm{P}$ and $\mathrm{K}$ with increasing doses of PS in black oat/corn/turnip succession.

Regarding the variables of production of wheat grain, fertilization with PS influenced only the TGW variable, for which the treatments of 80 and $160 \mathrm{~m}^{3} \mathrm{ha}^{-1}$ provided a higher value than the mineral NPK control (Table 4). If the high input of $\mathrm{N}$ is considered in these two treatments with 205.6 and $411.2 \mathrm{~kg} \mathrm{ha}^{-1}$, respectively, shown in Table 1, the results oppose those of Espindula et al. (2010) and Teixeira Filho et al. (2010), who found a negative linear correlation between increased levels of $\mathrm{N}$ and TGW. This justifies that higher $\mathrm{N}$ availability increases the number of $\mathrm{G} / \mathrm{S}$, which may compete for photoassimilates and lack for grain filling. The author raised yet another hypothesis that the increased supply of $\mathrm{N}$ increases plant mass, causing selfshading and loss of photosynthetic efficiency of plants, a fact that was not observed in this experiment, as noted in DM yield shown in Table 2. PS probably favored $\mathrm{N}$ uptake by the plant until the period of grain filling, depending on the slow net mineralization as verified by Fioreze et al. (2012) for very clayey soil.

Wheat PH was not influenced by the treatments (Table 4), although the increased supply of $\mathrm{N}$ could reflect in a decrease in PH (Cazetta et al., 2008; Teixeira Filho et al., 2010), depending on the increase of G/S and decrease of $\mathrm{TGW}$, as discussed in the preceding paragraph. However, the largest TGW may have been responsible for annulling the decline of PH.

Wheat productivity did not differ statistically (Table 4), which can be due to the fact that the area remained fallow in the previous year. Sartor et al. (2012) obtained linear increments in wheat yield with increasing doses of PS up to $60 \mathrm{~m}^{3} \mathrm{ha}^{-1}$ in three crops, and with this dose, obtaining higher yield than mineral fertilization, with an average of 2,$8 ; 10.55 \mathrm{~kg} \mathrm{ha}^{-1}$ in the three crops, very similar to the treatment of $40 \mathrm{~m}^{3} \mathrm{ha}^{-1}$ of this study.

Corn did not differ in TGW and yield among treatments of PS and the controls (Table 4). Seidel et al. (2010) found no difference in the corn yield with PS in relation to mineral fertilization, suggesting that it is an effective alternative for the farmer. Costa et al. (2011) did not obtain satisfactory corn yield grown after fertilized wheat, respectively, with 25 and $38 \mathrm{~m}^{3} \mathrm{ha}^{-1}$ of PS, although in the first year, when grown after wheat, the corn development was favored due to residual fertilization of that given to wheat. However,

Table 3: Accumulation of N, P and K by DM ((Dry matter) of wheat and corn shoots, fertilized with mineral NPK and PS (pig slurry))

\begin{tabular}{|c|c|c|c|c|c|c|}
\hline \multirow{3}{*}{ Treatments } & \multicolumn{3}{|c|}{ Wheat } & \multicolumn{3}{|l|}{ Corn } \\
\hline & $\mathbf{N}$ & $\mathbf{P}$ & $\mathbf{K}$ & $\mathbf{N}$ & $\mathbf{P}$ & $\mathbf{K}$ \\
\hline & \multicolumn{6}{|c|}{ kg ha $^{-1}$} \\
\hline No fertilizer $^{(1)}$ & $82.1^{(-2)}$ & 10.6 & $152.6^{(-2)}$ & $97.7^{(-2)}$ & $25.9^{(-2)}$ & $102.0^{(-2)}$ \\
\hline $40 \mathrm{~m}^{3} \mathrm{ha}^{-1} \mathrm{PS}$ & $117.7^{(+1)}$ & 13.7 & 211.4 & $159.1^{(+1)}$ & $37.7^{(+1)}$ & $126.5^{(-2)}$ \\
\hline $80 \mathrm{~m}^{3} \mathrm{ha}^{-1} \mathrm{PS}$ & $123.7^{(+1)}$ & $17.7^{(+1)}$ & $223.3^{(+1)}$ & $158.0^{(+1)}$ & $40.9^{(+1)}$ & $166.3^{(+1)}$ \\
\hline $160 \mathrm{~m}^{3} \mathrm{ha}^{-1} \mathrm{PS}$ & $125.4^{(+1)}$ & $19.9^{(+1)}$ & $225.9^{(+1)}$ & $170.7^{(+1)}$ & $41.1^{(+1)}$ & $187.1^{(+1)}$ \\
\hline Mineral NPK ${ }^{(2)}$ & $126.7^{(+1)}$ & $15.8^{(+1)}$ & $236.5^{(+1)}$ & $159.0^{(+1)}$ & $38.0^{(+1)}$ & $179.8^{(+1)}$ \\
\hline $\mathrm{CV}(\%)$ & 11.7 & 22.0 & 16.4 & 15.9 & 8.5 & 14.3 \\
\hline $\operatorname{Pr}>\mathrm{F}$ & 0.0025 & 0.0223 & 0.0338 & 0.0068 & $<0.0001$ & 0.0005 \\
\hline
\end{tabular}

${ }^{(1)}$ No fertilizer control, ${ }^{(2)}$ Mineral NPK control; *Means followed by: ${ }^{(+1)}$ significant and higher than the no fertilizer control, ${ }^{(-2)}$ significant and lower than the mineral NPK control by Dunnett test at $5 \%$ probability. 
Table 4: Response of wheat/corn succession in TGW (thousand grain weight - grams), Yield $\left(\mathrm{kg} \mathrm{ha}^{-1}\right)$ and PH $\left(\mathrm{kg} \mathrm{hl}^{-1}\right)$ fertilized with PS (pig slurry) and mineral fertilizer

\begin{tabular}{|c|c|c|c|c|c|}
\hline \multirow{2}{*}{ Treatments } & \multicolumn{3}{|c|}{ Wheat } & \multicolumn{2}{|c|}{ Corn } \\
\hline & TGW* & Yield & HW & TGW & Yield \\
\hline No fertilizer ${ }^{(1)}$ & 32.4 & $2,706.0$ & 79.2 & 278.0 & $13,309.9$ \\
\hline $40 \mathrm{~m}^{3} \mathrm{ha}^{-1} \mathrm{PS}$ & 31.2 & $2,808.0$ & 77.3 & 269.9 & $13,690.1$ \\
\hline $80 \mathrm{~m}^{3} \mathrm{ha}^{-1} \mathrm{PS}$ & $33.1^{(+2)}$ & $3,337.0$ & 78.3 & 264.1 & $14,685.2$ \\
\hline $160 \mathrm{~m}^{3} \mathrm{ha}^{-1} \mathrm{PS}$ & $33.6^{(+2)}$ & $2,873.0$ & 78.4 & 267.2 & $14,721.0$ \\
\hline Mineral NPK ${ }^{(2)}$ & 31.3 & $3,165.6$ & 78.5 & 277.3 & $14,023.2$ \\
\hline General Average & 32.3 & $2,978.0$ & 78.4 & 271.3 & $14,085.1$ \\
\hline $\mathrm{CV}(\%)$ & 2.7 & 19.6 & 1.1 & 7.2 & 11.7 \\
\hline $\operatorname{Pr}>F$ & 0.0009 & 0.5411 & 0.0738 & 0.8075 & 0.6955 \\
\hline
\end{tabular}

(1) No fertilizer control, ${ }^{(2)}$ Mineral NPK control; *Means followed by: ${ }^{(+2)}$ significant and higher than the mineral NPK control by Dunnett test at $5 \%$ probability.

Sartor et al. (2012) found a positive response with increasing doses up to $60 \mathrm{~m}^{3} \mathrm{ha}^{-1}$ of PS, reaching a $55 \%$ increase in yield compared to the zero dose, with very close values to mineral fertilization. A yield increase of $2.86,10.33$ and $10.60 \%$ is observed, compared to control without fertilization for treatments of 40,80 and $160 \mathrm{~m}^{3}$ ha ${ }^{1}$ of PS, respectively. Attention is brought to the low increment provided when the dose of 80 is doubled to 160 $\mathrm{m}^{3} \mathrm{ha}^{-1}$.

Further studies should address the efficiency of PS doses, as reported by Ceretta et al. (2005), and Cassol et al. (2005). The latter authors found a maximum technical efficiency at the dose of $143 \mathrm{~m}^{3} \mathrm{ha}^{-1}$, but warn that it is not feasible to achieve it, as $59 \mathrm{~m}^{3} \mathrm{ha}^{-1}$ would be needed to increase the remaining $10 \%$.

\section{CONCLUSIONS}

Compared with the mineral NPK source, PS is an efficient alternative and can be used as a source of nutrients in wheat/corn succession.

\section{REFERENCES}

Aita C, Chiapinotto IC, Giacomini SJ, Hübner AP \& Marques MG (2006) Decomposição de palha de aveia preta e dejetos de suínos em solo sob plantio direto. Revista Brasileira de Ciência do Solo, 30:149-161.

Aita C \& Giacomini SJ (2008) Nitrato no solo com a aplicação de dejetos líquidos de suínos no milho em plantio direto. Revista Brasileira de Ciência do Solo, 32:2101-2111.

Aita C, Port O \& Giacomini SJ (2006) Dinâmica do nitrogênio no solo e produção de fitomassa por plantas de cobertura no outono/inverno com o uso de dejetos de suínos. Revista Brasileira de Ciência do Solo, 30:901-910.

Araújo LAN, Ferreira ME \& Cruz MCP (2004) Adubação nitrogenada na cultura do milho. Pesquisa Agropecuária Brasileira, 39:771-777.

Assmann TS, Assmann JM, Cassol LC, Diehl RC, Manteli C \& Magiero EC (2007) Desempenho da mistura forrageira de aveiapreta mais azévem e atributos químicos do solo. Revista Brasileira de Ciência do Solo, 31:1515-1523.
Brum AL \& Heck CRA (2005) Economia do Trigo no Rio Grande do Sul: Breve Histórico do Cereal na Economia do Estado. Porto Alegre, Análise. 44p.

Cassol PC, Costa AC, Ciprandi O, Pandolfo CM \& Ernani PR (2012) Disponibilidade de macronutrientes e rendimento de milho em latossolo fertilizado com dejeto suíno. Revista Brasileira de Ciência do Solo, 36:1911-1923.

Cazetta DA, Fornasier Filho D, Arf O \& Germani R (2008) Qualidade industrial de trigo e triticale submetidos a adubação nitrogenada no sistema de plantio direto. Bragantia, 67:741750 .

Ceretta CA, Basso CJ, Pavinato PS,Trentin EE \& Girotto E (2005) Produtividade de grãos de milho, produção de matéria seca e acúmulo de nitrogênio, fósforo e potássio na rotação aveia preta/milho/nabo forrageiro com aplicação de dejeto líquido de suínos. Ciência Rural, 35:1287-1285.

Corrêa JC, Nicoloso RS, Menezes JFS \& Benites VM (2011) Critérios técnicos para recomendação de biofertilizante de origem animal em sistemas de produção agrícolas e florestais. Concórdia, Embrapa suínos e aves. 55p. (Comunicado Técnico, 486).

Costa MSSM, Pivetta LA, Costa LAM, Pivetta LG, Castoldi G \& Steiner F (2011) Atributos físicos do solo e produtividade do milho sob sistemas de manejos e adubações. Revista Brasileira de Engenharia Agrícola e Ambiental, 15:810-815.

CQFS - Comissão de Química e Fertilidade do Solo (2004) Manual de adubação e calagem para os estados do Rio Grande do Sul e Santa Catarina. Porto Alegre, Sociedade Brasileira de Ciência do Solo. 400p.

Cruz CD (2006) Programa Genes: Biometria. Viçosa, Editora UFV. $382 \mathrm{p}$.

Cruz SCS, Pereira FRS, Santos JR, Albuquerque AW \& Pereira RG (2008) Adubação nitrogenada para o milho cultivado em sistema plantio direto, no estado de alagoas. Revista Brasileira de Engenharia Agrícola e Ambiental, 12:62-68.

Duete RRC, Muraoka T, Silva EC, Trivelin PCO \& Ambrosano EJ (2008) Manejo da adubação nitrogenada e utilização do nitrogênio $\left({ }^{15} \mathrm{~N}\right)$ pelo milho em Latossolo Vermelho. Revista Brasileira de Ciência do Solo, 32:161-171.

EMBRAPA - Empresa Brasileira de Pesquisa Agropecuária (2006) Sistema Brasileiro de Classificação de Solos. $2^{\mathrm{a}}$ ed. Rio de Janeiro, Embrapa-Solos. 306p.

Espindula MC, Rocha VS, Souza MA, Grossi JAS \& Souza LT (2010) Doses e Formas de Aplicação do Nitrogênio no Desenvolvimento e Produção da Cultura do Trigo. Ciência Agrotecnologia, 34:1404-1411. 
Fioreze C, Ceretta CA, Giacomini SJ, Trentin SJ \& Lorensini F (2012) Liberação do N em solos de diferentes texturas com ou sem adubos orgânicos. Ciência Rural, 42:1187-1192.

Giacomini SJ \& Aita C (2008) Cama sobreposta e dejetos líquidos de suínos como fonte de nitrogênio ao milho. Revista Brasileira de Ciência do Solo, 32:195-205

Giacomini SJ, Aita C, Miola ECC \& Recous S (2008) Mineralização do carbono da palha de aveia e dejetos de suínos aplicados na superfície ou incorporados ao solo. Revista Brasileira de Ciência do Solo, 32:2661-2668.

Gomes RF, Silva AG, Assis RL \& Pires FR (2007) Efeito de doses e da época de aplicação de nitrogênio nos caracteres agronômicos da cultura do milho sob plantio direto. Revista Brasileira de Ciência do Solo, 31:931-938.

Konzen EA (2006) Viabilidade ambiental e econômica de dejetos de suínos. Sete Lagoas, Embrapa Milho e Sorgo. 27p. (Documentos, 59).

Konzen EA (1983) Manejo e utilização de dejetos de suínos. Concórdia, Embrapa Suínos e Aves. 32p. (Circular Técnica, 6).

Lourenzi CR, Ceretta CA, Silva LS, Girotto E, Lorensini F, Tiecher TF, De Conti L, Trentin G \& Brunetto G (2013) Nutrients in soil layers under no-tillage after successive pig slurry applications. Revista Brasileira de Ciência do Solo, 37:57-167.

Lourenzi CR, Ceretta CA, Silva LS, Trentin G, Girotto E, Lorensini F, Tiecher TF \& Brunetto G (2011) Soil chemical properties related to acidity under successive pig slurry application. Revis ta Brasileira de Ciência do Solo, 35:1827-1836.

Malavolta E (2006) Manual de nutrição mineral de plantas. Piracicaba, Editora Ceres. 631p.
Mata JF, Silva JC, Ribeiro JF, Afferi FS \& Vieira LM (2010) Produção de milho híbrido sob doses de esterco bovino. Pesquisa Aplicada \& Agrotecnologia, 3:125-134.

Moreno JA (1961) Clima do Rio Grande do Sul. Porto Alegre, Secretaria da Agricultura. 41p.

Pinnow C, Benin G, Viola R, Silva CL, Gutkoski LC \& Cassol LC (2013) Qualidade industrial do trigo em resposta à adubação verde e doses de nitrogênio. Bragantia, 72:20-28.

Sartor LR, AssmannAL, Assmann TS, Bigolin PE, Miyazawa M \& Carvalho PCF (2012) Effect of swine residue rates on corn, common bean, soybean and wheat yield. Revista Brasileira de Ciência do Solo, 36:661-669.

Seidel EP, Gonçalves-Junior AC,Vanin JP, Strey L, Schwantes D \& Nacke H (2010) Aplicação de dejetos de suínos na cultura do milho cultivado em sistema de plantio direto. Acta Scientiarum: Technology, 32:113-117.

Soratto RP, Pereira M, Costa TAM \& Lampert VN (2010) Fontes Alternativas e Doses de Nitrogênio no Milho Safrinha em Sucessão à Soja. Revista Ciência Agronômica, 41:511-518.

Tedesco MJ, Gianello C, Bissani CA, Bohnen H \& Volkweiss SJ (1995) Análise de solo, plantas e outros materiais. $2^{\mathrm{a}}$ ed. Porto Alegre, UFRGS. 174p.

Teixeira Filho MCM, Buzetti S, Andreotti M, Arf O \& Benett CGS (2010) Doses, fontes e épocas de aplicação de nitrogênio em trigo irrigado em plantio direto. Pesquisa agropecuária brasileira, 45:797-804.

Teixeira Filho MCM, Buzetti S, Alvarez RCF, Freitas JG, Arf O \& Sá ME (2008) Desempenho agronômico de cultivares de trigo em resposta a população de plantas e a adubação nitrogenada. Científica, 36:97-106. 